IRA-International Journal of Education \& Multidisciplinary Studies

ISSN 2455-2526; Vol.04, Issue 03 (2016)

Pg. no. 402-408

Institute of Research Advances

http://research-advances.org/index.php/IJEMS

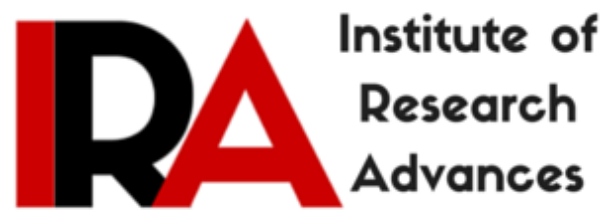

\title{
A study on relationship between achievement in mathematics and attitude towards mathematics of secondary school students'
}

\author{
Monoranjan Bhowmik ${ }^{1}$ \& Bharati Banerjee $(\text { Roy })^{2}$ \\ ${ }^{1}$ Vidyasagar Teachers' Training College \\ Paschim Medinipur, Pin - 721101 \\ West Bengal, India. \\ ${ }^{2}$ Department of Education \\ Rabindra Bharati University \\ Kolkata-700050, India.
}

Type of Review: Peer Reviewed.

DOI: http://dx.doi.org/10.21013/jems.v4.n3.p7

\section{How to cite this paper:}

Bhowmik, M., \& Banerjee (Roy), B. (2016). A study on relationship between achievement in mathematics and attitude towards mathematics of secondary school students'. IRA International Journal of Education and Multidisciplinary Studies (ISSN 2455-2526), 4(3), 402-408. doi:http://dx.doi.org/10.21013/jems.v4.n3.p7

(C) Institute of Research Advances

\section{(cc) EY-NC}

This work is licensed under a Creative Commons Attribution-Non Commercial 4.0 International License subject to proper citation to the publication source of the work.

Disclaimer: The scholarly papers as reviewed and published by the Institute of Research Advances (IRA) are the views and opinions of their respective authors and are not the views or opinions of the IRA. The IRA disclaims of any harm or loss caused due to the published content to any party. 


\section{ABSTRACT}

The purpose of this study was to investigate high school students' attitude towards mathematics and achievement in mathematics. For this purpose, the methodology employed in this study was a descriptive type. The participants of this study consisted of 394 secondary (class ten) students from six different high schools. The Mathematics Attitude Scale and Mathematics achievement questioner developed and standardized by the authors. The data was quantitatively analysed by using independent samples t-tests and Pearson's correlation coefficient (0.05 significant level) using SPSS software. Findings showed that in gender difference there had significant difference on the students' attitude towards mathematics, though there is not so significant difference in achievement in mathematics. Also there is a significant positive correlation between attitude towards mathematics and achievement in mathematics.

Keywords: Mathematics, Attitude, Academic achievement, Gender, School type.

\section{Introduction}

Irrespective of all countries, cast, gender etc much effort is spent in considering the cognitive outcomes related to mathematics classroom learning: how well the students can retrieve, understand or use their learnt knowledge in different situations. However, attitudes concerning with mathematics there are two main things. One is attitudes towards mathematics are likely to be some extent of multi-dimensional and not easily measured as a number, score or grade. Another one, attitudes towards mathematics almost certainly affects future learning while experiences in learning mathematics will generate attitudes towards mathematics. Basically attitude is a tendency attributed to the individual and regularly constitutes his/her thoughts, feelings and behaviours related to the psychological incident. The power of the attitude is equal to the total cognitive, sensational and behavioural aspects. Attitude is a mental, sensational and behavioural objection to pre-tendency of the individual organized depending on him and any object around him, social issue, object or experience against an incident, information, feeling and motivation (İnceoğlu, 2004, 19).

Several studies and researches have been done to find the different factors that influence the students to achievement in their mathematics. Brown and Abell (1965) studied the relationship between attitude and achievement related to some subjects and they found that the correlation between attitude and achievement with arithmetic was higher than with any other subject (eg. spelling, reading, or language). Dutton (1962) found that students' attitudes toward arithmetic in college are correlated positively with their arithmetic marks from elementary school but the correlation was not high. Often, the studies on relationship between students' attitude and the students' academic achievements show a positive relationship (Mohd, Mahmood, \& Ismail, 2011; Bramlett \& Herron, 2009; Nicolaidou \& Philippou, 2003; Papanastasiou, 2000; Ma \& Kishor, 1997). Hence students' attitude towards mathematics is a major factor that might influence the performance of the students. Due to this several studies has been conducted in different countries in order to find out the students attitude towards mathematics (Tahar, Ismail, Zamani \& Adnan, 2010; Tezer \& Karasel, 2010; Maat \& Zakaria, 2010; Bramlett \& Herron, 2009; Köğce, Yıldız, Aydın, \& Altındağ, 2009; Tapia \& Marsh, 2004; Fennema \& Sherman, 1976) and hence to use these data to suggest the low performance of students and factors affecting it. However, Ethington and Wolfle $(1984,1986)$ offered an equation summarising the way in which attitude toward mathematics causes achievement in mathematics. However, they 
go on to argue that the relationship may well be bilateral: "Although it might be argued that enrolment in mathematics courses is likely to affect attitudes toward mathematics, an equally plausible argument may be made that these attitudes affect decisions to enrol in mathematics courses. Thus, specifying any unidirectional causal relationship between these factors would be inappropriate." (Ethington and Wolfle, 1986: 66) Many consider that attitude toward mathematics and achievement in mathematics influence each other.

The aim of this research is to find out the relationship between achievement in mathematics and attitude towards mathematics of secondary school students'. The research will focuses on finding the students' attitude towards mathematics, achievement in mathematics and also finding the significant relation between students' attitude towards mathematics and achievement in mathematics with regard to gender of the students.

\section{Research Methodology \\ Research questions}

This study aimed to investigate the high school students' achievement in mathematics and attitude towards mathematics in terms of their gender difference. Also the correlation between achievement and attitude of the secondary students. The literature have revealed that few studies investigating students' attitude, achievement in mathematics levels towards mathematics and achievement in mathematics according to gender, school type and class level have been conducted. Therefore, the answers to the following research questions are sought;

1. What are the students' achievement levels in mathematics of the secondary students with regard to gender?

2. What are the students' attitudes towards mathematics of the secondary students with regard to gender?

3. Are there exists any relationships between attitude towards mathematics and achievement in mathematics of the secondary students' with regard to gender?

\section{Hypotheses of the study}

To find out the considerable response in respect of above quarries researchers used the following null hypothesis.

$\mathrm{HO}_{1}$ : There is no significant difference between mean achievement in mathematics of boys and girls of the secondary students.

$\mathrm{HO}_{2}$ : There is no significant difference between mean attitude towards mathematics of boys and girls of the secondary students.

$\mathrm{HO}_{3}$ : There is no significant correlation between achievement in mathematics and attitude towards mathematics of the secondary students.

\section{Population and Sample}

In the proposed study, authors selected the population is the secondary students of Jangal-Mahal of West-Bengal (India) under West-Bengal Board of Secondary Education (WBBSE).

The researchers used stratified cluster sampling in which we have 29 blocks and 4 subdivisions of the district Paschim-Medinipur of Jangal-Mahal of West-Bengal. Out of these specially eleven blocks and one part of a sub-division is in the portion of Jangal-Mahal. Then we had select Secondary school from these twelve areas preserving randomness as far as possible. 
We have selected six schools from the said area. The sample size of the students of this study is 394.

Table 1. Distribution of students in this study according to schools

\begin{tabular}{llllll}
\hline $\begin{array}{l}\text { Sl. } \\
\text { No. }\end{array}$ & Type of School & $\begin{array}{l}\text { No. of } \\
\text { School }\end{array}$ & Boys & Girls & Total \\
\hline $\mathbf{1}$ & Co-ed School & 3 & 81 & 99 & 180 \\
$\mathbf{2}$ & Girls School & 1 & 0 & 79 & 79 \\
$\mathbf{3}$ & Boys School & 1 & 72 & 0 & 72 \\
$\mathbf{4}$ & High Madrasha & 1 & 28 & 35 & 63 \\
& School (Co-ed) & & & & \\
& Total & 6 & 181 & 213 & 394 \\
\hline
\end{tabular}

\section{Tools Used}

To conducting this study we used the following tools.

1. Self constructed standardized achievement test used for measure of mathematics performance of the secondary students.

2. Self constructed standardized questioner prepared to measure the attitude towards mathematics of the secondary students.

In order to evaluate the students' attitudes towards mathematics, a Likert type mathematics attitude scale developed and standardized by the authors. There are four different dimension i.e. confidence, usefulness, enjoyment and importance in daily life including positive and negative level of affect concerning mathematics. The scheme of scoring involved different weighting such as for strongly agree was given a weight 5 , agree a weight of 4 , undecided a weight of 3 , disagree a weight of 2 , strongly disagree a weight of 1 in respect of responses, imparting to positive statement. The scoring is just reverse for negative worded items. The Cronbach's alpha reliability of the scale was found as 0.89 , standardized mean is 90.03 and standard deviation 18.66. In this scale, there were total 30 items out of these 17 positive and 13 negative statements. Therefore the highest possible points to be obtained from the 30 statements are 150 points, while the lowest is 30 points. If the points' level is high, this would show that the attitude towards the Mathematics lesson is high. Also for asses the students' achievement in mathematics, an achievement test (full marks 50)constructed by the authors on the basis of the syllabus of West Bengal School of Secondary Education .The Cronbach's alpha reliability of the achievement test was found as 0.92 , standardized mean is 28.4 and standard deviation 9.77 .

\section{Data analysis}

In this study, for analysis of collected data quantitatively, the researcher used descriptive and corelational statistics.

All analyses were performed by using the Statistical Package for Social Sciences (SPSS) software. Two dependent variables were measured in the study, one is attitude toward mathematics and another one is achievement in mathematics. The independent variable measured the gender of students. The data was analysed by using independent samples t-tests 
and correlation for main effect at the 0.05 level of significance.

Table 2. Achievement Score and Attitude score of Students

\begin{tabular}{|c|c|c|c|c|}
\hline \multirow{2}{*}{ Achievement } & $\begin{array}{c}\text { Gender of } \\
\text { Students }\end{array}$ & $\mathrm{N}$ & Mean & Std. Deviation \\
\cline { 2 - 5 } & $\mathrm{M}$ & 181 & 21.02 & 7.15 \\
\hline \multirow{2}{*}{ Attitude } & $\mathrm{F}$ & 213 & 19.65 & 6.93 \\
\cline { 2 - 5 } & $\mathrm{M}$ & 181 & 71.70 & 18.06 \\
\hline
\end{tabular}

Table 3. t-test of Achievement Score of Students

\begin{tabular}{|c|c|c|c|c|c|}
\hline & $\begin{array}{c}\text { Mean } \\
\text { Differenc } \\
\mathrm{e}\end{array}$ & $\begin{array}{c}\text { Std. Error } \\
\text { Difference }\end{array}$ & $\begin{array}{c}\text { Degree of } \\
\text { freedoms }\end{array}$ & t-value & Significant \\
\hline $\begin{array}{c}\text { Equal variances } \\
\text { not assumed }\end{array}$ & 1.37 & 0.71 & 392 & 1.922 & .055 \\
\hline
\end{tabular}

Table 4. t-test of Attitude Score of Students

\begin{tabular}{|c|c|c|c|c|c|}
\hline & $\begin{array}{c}\text { Mean } \\
\text { Differenc } \\
\mathrm{e}\end{array}$ & $\begin{array}{c}\text { Std. Error } \\
\text { Difference }\end{array}$ & $\begin{array}{c}\text { Degree of } \\
\text { freedoms }\end{array}$ & t-value & Significant \\
\hline $\begin{array}{c}\text { Equal variances } \\
\text { not assumed }\end{array}$ & 4.38 & 1.75 & 392 & 2.502 & .013 \\
\hline
\end{tabular}

Table 5. Correlations between Achievement score and Attitude Score of Students

\begin{tabular}{|c|c|c|c|}
\hline & & \multicolumn{2}{|c|}{ Achievement of Attitudes of } \\
\hline & & Students & Students \\
\hline \multirow{2}{*}{$\begin{array}{l}\text { Achievement of } \\
\text { Students }\end{array}$} & Pearson Correlation & 1 & 0.307 \\
\hline & Significant & -------------- & 0.000 \\
\hline \multirow{2}{*}{$\begin{array}{l}\text { Attitudes of } \\
\text { Students }\end{array}$} & Pearson Correlation & 0.307 & 1 \\
\hline & Significant & 0.000 & ----------- \\
\hline
\end{tabular}

\section{Findings}

The findings of the study are given according to the research questions.

H01: There is no significant difference between mean achievement in mathematics of boys and girls of the secondary students.

As shown in Table 3, there is no significant difference between gender concerning the students' achievement in mathematics $\left[\mathrm{t}_{(394)}=1.922, \mathrm{p}>0.05\right]$. Though findings in Table 2 showed that boys students mean scores (21.02) on their mathematical achievement towards mathematics little more than girls students mean scores (19.65). Hence, it can be said with $95 \%$ confident that there is no significant difference in mathematical achievement between boys' and girls'. 
$\mathbf{H O}_{2}$ : There is no significant difference between mean attitude towards mathematics of boys and girls of the secondary students.

As shown in Table 4, there is a significant difference between gender concerning the students' attitude towards mathematics $\left[\mathrm{t}_{(394)}=2.482, \mathrm{p}<0.05\right]$. Here findings showed in Table 2 that boys students mean scores (71.70) on their mathematical attitude towards mathematics more than girls students mean scores (67.32). Hence, it can be said with $95 \%$ confident that there is a significant difference in mathematical achievement between boys' and girls'.

H03: There is no significantly co-relationship between attitude towards mathematics and achievement in mathematics of the secondary students.

As displayed in Table 5, the test of hypothesis at 95\% (0.05significance level) confidence level revealed a low correlation of 0.307 . Thus, per this study, even though there is a positive correlation between attitude towards mathematics and achievement in mathematics, the correlation is significant. Hence, we reject the null hypothesis. There is a significant corelationship between attitude towards mathematics and achievement in mathematics of the secondary students.

\section{Discussion and Conclusion}

In the present study, the achievement in mathematics and attitudes towards mathematics attending different high schools were investigated in terms of gender difference. When the results of students' achievement in mathematics and attitudes towards mathematics were examined according to gender, an interesting statistical difference was found between achievement in mathematics and attitudes towards mathematics in terms of gender. Here findings showed that boys students mean scores (21.02) on their mathematical achievement in mathematics little more than girls students mean scores (19.65) and there is no significant difference between gender concerning the students' achievement towards mathematics $\left[\mathrm{t}_{(394)}=\right.$ $1.922, \mathrm{p}>.05]$. Whereas there is significant difference among boys and girls students regarding attitude towards mathematics $\left[\mathrm{t}_{(394)}=2.482, \mathrm{p}<.05\right]$ and boys students mean scores (71.70) on their mathematical achievement towards mathematics little more than girls students mean scores (67.32). As displayed in Table 5, the test of hypothesis at 95\% (0.05significance level) confidence level revealed a low correlation of 0.301 . Thus, per this study, even though there is no significant difference in achievement in mathematics among boys and girls, there is a significant difference found towards attitude in mathematics. Also we can conclude that there is a positive correlation between attitude and achievement i.e. if attitude towards mathematics be increased then their achievement in mathematics certainly would increase.

\section{REFERENCES}

1. Akın A, Kurbanoğlu NI, Takunyacı M (2009). The validity and reliability study of the Turkish version of the revised Mathematics achievement in mathematics rating scale, paper presented at the 30th International Conference of the Stress \& Achievement in mathematics Research Society (STAR), July 16

2. Alexander L, Martray C (1989). The development of an abbreviated version of the Mathematics Achievement in mathematics Rating Scale. Measure. Eval. Counsell. Dev. 
22:143-150.

3. Ashcraft MH, Faust MW (1994). Mathematics Achievement in mathematics and Mental Arithmetic Performance: An Exploratory Investigation. Cognition Emotion 8(22):97-125.

4. Bishop, A. J. (1996). International handbook of mathematics education. Springer.

5. Cater, G. S., \& Norwood, K. S. (1997), A study of African-American College students' attitude towards mathematics. Journal of Mathematical Sciences \& Mathematics Education, 4(2), 43-51.

6. Cemen PB (1987). The Nature of Mathematics Achievement in mathematics, ERIC Document Dissertation, ED 287729.

7. Dede Y (2008). Mathematics Achievement in mathematics Questionnaire: Development and Validation. Essays in Education. Winter 23:36 -55.

8. Doepken, D., Lawsky, E., \& Padwa, L., The relationship between teacher and students ${ }^{\text {ee }}$ belief about mathematics. School science and mathematics, 97(2), 62-67.

9. Graziano, A. M. \& Raulin, M.L. (2000), Teachers' beliefs about mathematical problem solving in the elementary school. School Science and Mathematics, 94(6), 314-322

10. Klein, M. (2004).Elementary school Teachers ${ }^{\text {ee }}$ Attitude toward mathematics: The impact on studentse autonomous learning skills. School Science and mathematics, 9(16), 265270.

11. Ma, X. \& Kishor, N. (1997). Assessing the relationship between attitude toward mathematics and achievement in mathematics: A meta-analysis. Journal for Research in Mathematics Education, 28(1), 27-47.

12. Nicolaidou, M. \& Philippou, G. (2003), Factors that influence students in mathematics achievement. International Journal of Academic Research, 3(3),49-54.

13. Norwwod, KS (1994). The Effect of instructional approach on Mathematics achievement in mathematics and achievement. School Sci. Math. 94(5):248-254.

14. Orton, A., Orton, D., \& Frobisher, L. J. (2004), Attitudes towards mathematics and predictors of collecge mathematics grades: gender difference in a 4-year business college. Journal of Education for Business, 74(1), 34-38.

15. Plake BS, Parker CS (1982). The development and validation of a revised version of the Mathematics Achievement in mathematics Rating Scale. Educ. Psychol. Meas. 42:551557.

16. Richardson FC, Suinn RM (1972). The Mathematics Achievement in mathematics Rating Scale: Psychometric Data. J. Counsel. Psychol. 19: 39-47.

17. Routledge. Fan, L., Quek, K. S., Zhu, Y., Yeo, S. M., Lionel, P., \& Lee, P. Y. (2005), Images of mathematics, values and gender. In S. Johnston-Wilder \& B. Allen (Eds.), Mathematics education: exploring the culture of learning.

18. Tapia, M. \& Marsh II, G. E. (2004), Students ${ }^{\text {ee }}$ Attitude toward mathematics: The Use of Factor Analysis in Determining the Criteria. Procedia-Social and Behavioral Sciences, 8, 476-481. 